\title{
Black Point Reaction of Durum and Common Wheat Cultivars Grown Under Irrigation in Southern Saskatchewan
}

M. R. Fernandez, J. M. Clarke, and R. M. DePauw, Semiarid Prairie Agricultural Research Centre, Agriculture and Agri-food Canada, P.O. Box 1030, Swift Current, Saskatchewan S9H 3X2; R. B. Irvine, Brandon Research Centre, Agriculture and Agri-Food Canada, P.O. Box 1000, Brandon, Manitoba R7A 5Y3; and R. E. Knox, Semiarid Prairie Agricultural Research Centre, Agriculture and Agri-food Canada

\begin{abstract}
Fernandez, M. R., Clarke, J. M., DePauw, R. M., Irvine, R. B., and Knox, R. E. 2000. Black point reaction of durum and common wheat cultivars grown under irrigation in southern Saskatchewan. Plant Dis. 84:892-894.

Six durum (Triticum turgidum L. var. durum) and six common (T. aestivum L.) wheat cultivars were compared for reaction to black point under irrigation at two locations in southern Saskatchewan in 1990 to 1992 and 1994. There were individual varietal differences in black point levels within each of the species. The Canada Western Soft White Spring wheat Fielder was the most susceptible and the Canada Western Red Spring wheat Katepwa was the most resistant to black point. The location-cultivar-year interaction was a significant source of variation and a crossover cultivar-environment interaction was significant, suggesting that rank order of cultivars differed with environment. The durum wheat had significantly higher black point levels than the common wheat cultivars in three of the seven environments conducive to black point, two of which were in 1992, and had high overall black point levels. This greater black point severity on the durum wheat cultivars might have been due to cool, wet weather conditions and frosts during seed development that delayed ripening.
\end{abstract}

Black point of wheat (Triticum spp.) is commonly associated with Alternaria spp. and Cochliobolus sativus (Ito \& Kuribayashi) Drechs. ex Dastur (anamorph Bipolaris sorokiniana (Sacc.) Shoemaker) $(5,6)$. However, Williams (10) has reported no association between A. alternata (Fr.:Fr.) Keissl. and black point incidence. This kernel discoloration reduces the commercial grade of wheat (2), causing economic losses to producers.

Black point has been reported in western Canada in irrigated durum (T. turgidum L. var. durum) and common wheat (T. aestivum L.) $(5,6)$, and is more severe in irrigated than in rainfed crops $(3,7)$.

The susceptibility to black point of wheat cultivars of different species or quality classes currently grown in western Canada has not been evaluated. Durum wheat has been reported as equally or more susceptible to black point $(8,9)$ than common wheat. However, these reports were either conducted on a limited number of cultivars or included no data.

Corresponding author: M. R. Fernandez

E-mail: fernandezm@em.agr.ca

This research was carried out with financial assistance from the Canada Saskatchewan Irrigation Based Economic Development Program.

Accepted for publication 6 March 2000.

Publication no. D-2000-0531-01R

(c) 2000 The American Phytopathological Society
This study was undertaken to compare the black point reaction of six durum and six common wheat cultivars which are currently registered for use in western Canada and have potential for production under irrigation.

\section{MATERIALS AND METHODS}

Trials were grown under overhead irrigation at Swift Current and Outlook from 1990 to 1994, using a two-replicate, randomized complete block design. The 1990 to 1992 trials were described by Fernandez et al. (6). The six durum and six common wheat registered cultivars used for this study were the Canada Western Amber Durum (CWAD) cultivars Medora, Wak- ooma, Sceptre, Arcola, Plenty, and Kyle; the Canada Western Red Spring (CWRS) cultivars Katepwa and Laura; the Canada Prairie Spring (CPS) cultivars Genesis (white) and Biggar and AC Taber (red) (the latter was not in the 1990 test); and the Canada Western Soft White Spring (CWSWS) cultivar Fielder. The 1994 test consisted of the six durum and six common wheat cultivars above, plus the CWSWS cultivar AC Reed (excluded from the analyses). Plots were seeded on 11 May 1990, 23 May 1991, 11 May 1992, and 11 May 1994 at Swift Current; and 24 May 1990, 22 May 1991, 18 May 1992, and 25 May 1994 at Outlook. Plots consisted of four rows, $3 \mathrm{~m}$ long and $0.23 \mathrm{~m}$ (Swift Current) or $0.20 \mathrm{~m}$ (Outlook) apart. Adjacent plots were $0.45 \mathrm{~m}$ apart, and ranges were separated by 2-m alleys. Harvest was on 7 September in 1990 and 1991, 10 October in 1992, and 8 September in 1994 at Swift Current; and on 25 September 1990, 12 September 1991, 10 October 1992, and 20 September 1994, at Outlook. Irrigation water was applied by overhead sprinklers as required to maximize grain yield. Meteorological data (precipitation and temperature) were recorded at meteorological stations on site (Table 1).

Percent incidence of black point for each plot was the mean percent number of kernels with black point symptoms (a dark, brown-to-black discoloration) of three subsamples of 100 kernels each. Quality grades were also assigned to each sample based on black point tolerance levels set by
Table 1. Total rain and irrigation $(\mathrm{mm})$ and average maximum and minimum temperatures $\left({ }^{\circ} \mathrm{C}\right)$ for Swift Current and Outlook, 1990 to 1992 and 1994

\begin{tabular}{|c|c|c|c|c|c|}
\hline \multirow[b]{2}{*}{ Location, year } & \multirow[b]{2}{*}{$\operatorname{Rain}(\mathbf{m m})^{x}$} & \multicolumn{2}{|c|}{ Irrigation } & \multicolumn{2}{|c|}{ Temperature $\left({ }^{\circ} \mathbf{C}\right)^{\mathbf{w}}$} \\
\hline & & Amount $(\mathrm{mm})^{\mathrm{y}}$ & Period & Minimum & Maximum \\
\hline \multicolumn{6}{|l|}{ Swift Current } \\
\hline 1990 & $19.2(13)$ & $71.5(2)$ & 1-9 August & 11.4 & 25.7 \\
\hline 1991 & $33.3(7)$ & $106.0(3)$ & 1-13 August & 12.3 & 27.1 \\
\hline 1992 & 87.8 (27) & $47.6(1)$ & 1-11 August & 6.3 & 19.2 \\
\hline 1994 & $36.1(14)$ & $68.4(2)$ & 1-10 August & 10.2 & 24.7 \\
\hline \multicolumn{6}{|l|}{ Outlook } \\
\hline 1990 & $17.2(10)$ & $28.5(3)$ & 1-20 August & 9.9 & 25.2 \\
\hline 1991 & $10.6(5)$ & $22.0(1)$ & 1-9 August & 11.6 & 27.8 \\
\hline 1992 & $107.0(15)$ & $76.0(4)$ & 1-26 August & 5.9 & 19.7 \\
\hline 1994 & $61.0(16)$ & $\ldots$ & $\mathrm{NA}^{\mathrm{z}}$ & 9.9 & 24.3 \\
\hline
\end{tabular}

${ }^{\mathrm{w}}$ Mean minimum and maximum temperatures from 1 August to harvest.

${ }^{x}$ Amount of rain from 1 August to harvest (number of occurrences).

y Amount of irrigation in August (number of applications).

z NA = not applicable. 
the Canadian Grain Commission (2) as follows: for CWAD and CWSWS, $10 \%$ black point for No. 1, $15 \%$ for No. 2, and $35 \%$ for No. 3; for CWRS, $10 \%$ for No. 1 , $20 \%$ for No. 2, and $35 \%$ for No. 3; and for CPS, $20 \%$ for No. 1 and 35\% for No. 2.

Percentage data were subjected to an arcsine square root transformation prior to analysis of variance using general linear model (GLM) procedures (Statistical Analysis Systems, Inc., Cary, NC), with year as a random effect and location and genotype as fixed effects. When $F$ values were significant $(P<0.05)$, treatment means were compared using the least significant difference (LSD) test. The crossover interaction test of Azzalini and Cox, as described by Baker (1), was used to test for significant $(P<0.05)$ changes in genotype rank over environments. Single degree of freedom contrasts compared black point percent incidence between durum and common wheat.

\section{RESULTS AND DISCUSSION}

A combined analysis of variance for black point incidence across years and locations showed significant $(P<0.05)$ effects (Table 2). Levels of black point were higher at Outlook (mean of 16\%) than at Swift Current (9\%). Overall, the lowest frequencies of black point were observed in 1991 and 1994 (5 and 6\%, respectively) and the highest in 1992 (27\%), with average levels in 1990 being intermediate $(12 \%)$ but not significantly different $(P>0.05)$ from those of 1994 . Rainfall was low and temperatures were somewhat high during seed development at both locations in 1990, 1991, and 1994 (Table 1). These weather conditions are typical of southern Saskatchewan. In 1992, the average maximum temperatures were lower at both locations. The same year there was also higher rainfall and two frosts during seed development, which delayed ripening. These observations might explain the higher levels of black point in 1992 than in the other years. In 1992, black point was also associated with a higher level of saprophytes isolated from diseased kernels than in 1991 (6).

According to the guidelines set by the Canadian Grain Commission (2), there

Table 2. Analysis of variance for black point incidence on 12 wheat cultivars grown at two locations in southern Saskatchewan in 1990 to 1992 and 1994

\begin{tabular}{lrc}
\hline Source of variation & df & Mean squares $^{\mathbf{z}}$ \\
\hline Location & 1 & $0.6848^{* *}$ \\
Year & 3 & $1.0475^{* *}$ \\
Location-year & 3 & $0.0264 \mathrm{NS}$ \\
Cultivar & 11 & $0.0624^{* *}$ \\
Cultivar-location & 11 & $0.0094 \mathrm{NS}$ \\
Cultivar-year & 32 & $0.0230 \mathrm{NS}$ \\
Cultivar-location-year & 32 & $0.0136^{* *}$ \\
Replicates (year-location) & 8 & $0.0456^{* *}$ \\
Error & 86 & 0.0056 \\
\hline
\end{tabular}

$\mathrm{z} *$ and $* *=$ significant at the $P<0.05$ and $P<0.01$ level, respectively; NS $=$ not significant. would have been downgrading due to black point levels for one or more cultivars in seven out of the eight environments in which this study was conducted (Table 3 ). The exception was Swift Current in 1991.

The interaction of cultivar-location was not significant $(P>0.05$; Table 2$)$, indicating that, despite levels of organisms usually associated with black point being different between the two locations (6), black point incidence in the cultivars tested remained consistent relative to each other. The interaction of cultivar-year was also not significant. However, the interaction of cultivar-year-location was significant $(P<$ 0.01 ), indicating that the reaction of the cultivars to black point was not consistent among individual environments. Thus, the black point data for individual cultivars are presented by environment (Table 4). The Azzalini-Cox test (1) for crossover interaction of cultivars was significant $(P<$ 0.05 ) for cultivar-environment, considering each year-location as an individual environment. The few changes in rank order observed occurred between 1992 and one or more of the other environments (Table 4). Differences among cultivars also tended to be greater in both 1992 tests than in the rest of the environments. Conner and Davidson (4) also reported variation among environments in the ranking of different common wheat genotypes based on their black point incidence.

The variability among cultivars was in general also greater in the Outlook environments than when conditions for black point development were not as favorable (i.e., most of the Swift Current environments; Table 4). There was no consistent difference in black point incidence among the CWAD cultivars across environments.

Table 3. Quality grade based on black point of durum and common wheat cultivars grown under irrigation at Swift Current (SwC) and Outlook (OutL) in southern Saskatchewan in 1990 to 1992 and $1994^{y}$

\begin{tabular}{|c|c|c|c|c|c|c|c|c|c|}
\hline \multirow[b]{2}{*}{ Class, cultivar $^{\mathrm{z}}$} & \multicolumn{2}{|c|}{1990} & \multicolumn{2}{|c|}{1991} & \multicolumn{2}{|c|}{1992} & \multicolumn{2}{|c|}{1994} & \multirow[b]{2}{*}{ Mean } \\
\hline & SwC & OutL & SwC & OutL & SwC & OutL & SwC & OutL & \\
\hline \multicolumn{10}{|l|}{ Durum wheat } \\
\hline \multicolumn{10}{|l|}{ CWAD } \\
\hline Arcola & $1.0 \mathrm{c}$ & $1.5 \mathrm{bc}$ & 1.0 & $1.0 \mathrm{~b}$ & $2.0 \mathrm{bc}$ & $3.0 \mathrm{bc}$ & $1.0 \mathrm{~b}$ & $1.0 \mathrm{~b}$ & 1.4 \\
\hline Kyle & $1.0 \mathrm{c}$ & $2.0 \mathrm{a}-\mathrm{c}$ & 1.0 & $1.0 \mathrm{~b}$ & $2.0 \mathrm{bc}$ & $3.5 \mathrm{ab}$ & $1.0 \mathrm{~b}$ & $3.0 \mathrm{a}$ & 1.8 \\
\hline Medora & $1.5 \mathrm{~b}$ & $3.5 \mathrm{a}$ & 1.0 & $1.0 \mathrm{~b}$ & $2.5 \mathrm{a}-\mathrm{c}$ & $4.0 \mathrm{a}$ & $1.0 \mathrm{~b}$ & $2.5 \mathrm{a}$ & 2.1 \\
\hline Plenty & $1.0 \mathrm{c}$ & $2.5 \mathrm{a}-\mathrm{c}$ & 1.0 & $1.0 \mathrm{~b}$ & $4.0 \mathrm{a}$ & $4.0 \mathrm{a}$ & $1.0 \mathrm{~b}$ & $3.0 \mathrm{a}$ & 2.2 \\
\hline Sceptre & $1.0 \mathrm{c}$ & $2.0 \mathrm{a}-\mathrm{c}$ & 1.0 & $1.0 \mathrm{~b}$ & $2.5 \mathrm{a}-\mathrm{c}$ & $3.0 \mathrm{bc}$ & $1.0 \mathrm{~b}$ & $1.0 \mathrm{~b}$ & 1.6 \\
\hline Wakooma & $1.0 \mathrm{c}$ & $1.5 \mathrm{bc}$ & 1.0 & $1.0 \mathrm{~b}$ & $3.5 \mathrm{ab}$ & $4.0 \mathrm{a}$ & $1.5 \mathrm{a}$ & $1.0 \mathrm{~b}$ & 1.8 \\
\hline Mean durum wheat & 1.1 & 2.2 & 1.0 & 1.0 & 2.8 & 3.6 & 1.1 & 1.9 & 1.8 \\
\hline \multicolumn{10}{|l|}{ Common wheat } \\
\hline \multicolumn{10}{|l|}{ CWRS } \\
\hline Katepwa & $1.0 \mathrm{c}$ & $2.0 \mathrm{a}-\mathrm{c}$ & 1.0 & $1.0 \mathrm{~b}$ & $1.0 \mathrm{c}$ & $2.0 \mathrm{~d}$ & $1.0 \mathrm{~b}$ & $1.0 \mathrm{~b}$ & 1.3 \\
\hline Laura & $1.0 \mathrm{c}$ & $3.0 \mathrm{ab}$ & 1.0 & $1.0 \mathrm{~b}$ & $2.5 \mathrm{a}-\mathrm{c}$ & $3.0 \mathrm{bc}$ & $1.0 \mathrm{~b}$ & $1.0 \mathrm{~b}$ & 1.7 \\
\hline \multicolumn{10}{|l|}{ CPS } \\
\hline AC Taber & & & 1.0 & $1.0 \mathrm{~b}$ & $1.0 \mathrm{c}$ & $2.0 \mathrm{~d}$ & $1.0 \mathrm{~b}$ & $1.0 \mathrm{~b}$ & 1.2 \\
\hline Biggar & $1.0 \mathrm{c}$ & $1.5 \mathrm{bc}$ & 1.0 & $1.0 \mathrm{~b}$ & $1.0 \mathrm{c}$ & $2.0 \mathrm{~d}$ & $1.0 \mathrm{~b}$ & $1.0 \mathrm{~b}$ & 1.2 \\
\hline Genesis & $1.0 \mathrm{c}$ & $1.0 \mathrm{c}$ & 1.0 & $1.0 \mathrm{~b}$ & $1.0 \mathrm{c}$ & $2.5 \mathrm{~cd}$ & $1.0 \mathrm{~b}$ & $1.0 \mathrm{~b}$ & 1.2 \\
\hline \multicolumn{10}{|l|}{ CWSWS } \\
\hline Fielder & $3.0 \mathrm{a}$ & $3.0 \mathrm{ab}$ & 1.0 & $3.0 \mathrm{a}$ & $3.5 \mathrm{ab}$ & $3.5 \mathrm{ab}$ & $1.0 \mathrm{~b}$ & $2.5 \mathrm{a}$ & 2.6 \\
\hline Mean common wheat & 1.4 & 2.1 & 1.0 & 1.3 & 1.7 & 2.3 & 1.0 & 1.3 & 1.5 \\
\hline
\end{tabular}

${ }^{y}$ Mean grade values followed by the same letter are not significantly different $(P>0.05)$ according to a least significant difference test.

${ }^{\mathrm{z}}$ CWAD = Canada Western Amber Durum, CWRS = Canada Western Red Spring, CPS = Canada Prairie Spring, and CWSWS = Canada Western Soft White Spring. 
Table 4. Percent incidence $(\%)$ of black point in registered durum and common wheat cultivars grown under irrigation at Swift Current and Outlook in southern Saskatchewan in 1990 to 1992 and 1994, and one degree of freedom contrasts between durum and common wheat cultivars ${ }^{\mathrm{x}}$

\begin{tabular}{|c|c|c|c|c|c|c|c|c|c|}
\hline \multirow[b]{2}{*}{ Class, cultivar ${ }^{y}$} & \multicolumn{2}{|c|}{1990} & \multicolumn{2}{|c|}{1991} & \multicolumn{2}{|c|}{1992} & \multicolumn{2}{|c|}{1994} & \multirow[b]{2}{*}{ Mean } \\
\hline & $\mathrm{SwC}$ & OutL & $\mathrm{SwC}$ & OutL & $\mathrm{SwC}$ & OutL & $\mathrm{SwC}$ & OutL & \\
\hline \multicolumn{10}{|l|}{ Durum wheat } \\
\hline \multicolumn{10}{|l|}{ CWAD } \\
\hline Arcola & $3 c-e$ & $9 \mathrm{c}$ & $5 \mathrm{ab}$ & $5 b-e$ & $20 \mathrm{c}-\mathrm{e}$ & $23 \mathrm{e}-\mathrm{g}$ & 4 & $8 \mathrm{~b}$ & 10 \\
\hline Kyle & $7 \mathrm{~b}-\mathrm{d}$ & $12 \mathrm{bc}$ & $3 \mathrm{bc}$ & $4 \mathrm{de}$ & $17 \mathrm{c}-\mathrm{e}$ & 34 a-e & 4 & $16 \mathrm{a}$ & 13 \\
\hline Medora & $10 \mathrm{a}-\mathrm{c}$ & $29 \mathrm{a}$ & $7 \mathrm{a}$ & $2 \mathrm{e}$ & $25 \mathrm{bc}$ & $38 \mathrm{a}-\mathrm{c}$ & 1 & $17 \mathrm{a}$ & 16 \\
\hline Plenty & $8 \mathrm{~b}-\mathrm{d}$ & $17 \mathrm{a}-\mathrm{c}$ & $5 \mathrm{ab}$ & $3 \mathrm{de}$ & $42 \mathrm{a}$ & $41 \mathrm{a}$ & 3 & $24 \mathrm{a}$ & 18 \\
\hline Sceptre & $2 \mathrm{de}$ & $11 \mathrm{bc}$ & $7 \mathrm{a}$ & $4 \mathrm{de}$ & $23 \mathrm{~cd}$ & $27 \mathrm{~b}-\mathrm{f}$ & 0 & $7 \mathrm{bc}$ & 10 \\
\hline Wakooma & $1 \mathrm{e}$ & $10 \mathrm{bc}$ & $1 \mathrm{de}$ & $2 \mathrm{e}$ & $43 \mathrm{a}$ & $46 \mathrm{a}$ & 9 & $7 \mathrm{bc}$ & 15 \\
\hline Mean durum wheat & 5 & 15 & 5 & 3 & 28 & 35 & 4 & 13 & $\ldots$ \\
\hline \multicolumn{10}{|l|}{ Common wheat } \\
\hline \multicolumn{10}{|l|}{ CWRS } \\
\hline Katepwa & $2 \mathrm{de}$ & $10 \mathrm{c}$ & $3 \mathrm{bc}$ & $6 b-d$ & $8 \mathrm{e}$ & $14 \mathrm{~g}$ & 1 & $1 \mathrm{~d}$ & 5 \\
\hline Laura & $5 c-e$ & $23 \mathrm{ab}$ & $3 \mathrm{bc}$ & $9 \mathrm{bc}$ & $17 \mathrm{c}-\mathrm{e}$ & $25 \mathrm{~d}-\mathrm{f}$ & 3 & $3 \mathrm{~cd}$ & 10 \\
\hline \multicolumn{10}{|l|}{ CPS } \\
\hline AC Taber & & & $1 \mathrm{e}$ & $10 \mathrm{~b}$ & $17 \mathrm{c}-\mathrm{e}$ & $26 c-f$ & 3 & $5 \mathrm{bc}$ & 9 \\
\hline Biggar & $16 \mathrm{ab}$ & $21 \mathrm{a}-\mathrm{c}$ & $2 \mathrm{~cd}$ & $5 \mathrm{c}-\mathrm{e}$ & $17 \mathrm{c}-\mathrm{e}$ & $21 \mathrm{fg}$ & 3 & $3 b-d$ & 10 \\
\hline Genesis & $6 c-e$ & $20 \mathrm{a}-\mathrm{c}$ & $2 c-e$ & $7 \mathrm{~b}-\mathrm{d}$ & $10 \mathrm{de}$ & 35 a-d & 3 & $7 \mathrm{bc}$ & 10 \\
\hline \multicolumn{10}{|l|}{ CWSWS } \\
\hline Fielder & $18 \mathrm{a}$ & $31 \mathrm{a}$ & $2 c-d$ & $21 \mathrm{a}$ & $38 \mathrm{ab}$ & $39 \mathrm{ab}$ & 3 & $21 \mathrm{a}$ & 21 \\
\hline Mean common wheat & 9 & 21 & 2 & 10 & 18 & 27 & 3 & 7 & $\ldots$ \\
\hline Contrasts $^{\mathrm{z}}$ & $0.015 \mathrm{NS}$ & $0.044 \mathrm{NS}$ & $0.002 \mathrm{NS}$ & $0.000 \mathrm{NS}$ & $0.199 * * *$ & $0.014 * * *$ & $0.006 \mathrm{NS}$ & $0.031 * * *$ & $\ldots$ \\
\hline
\end{tabular}

${ }^{\mathrm{x}}$ Mean percent incidence values of black point followed by the same letter are not significantly different $(P>0.05)$ according to a least significant difference test performed on arcsine-transformed data.

y CWAD = Canada Western Amber Durum, CWRS = Canada Western Red Spring, CPS = Canada Prairie Spring, and CWSWS = Canada Western Soft White Spring.

${ }^{\mathrm{z}}$ Durum versus common wheat: mean squares, ${ }^{*}$ and $* *=$ significant at $P<0.05$ and $P<0.01$, respectively; NS $=$ not significant.

The CWSWS cultivar Fielder consistently had the highest black point incidence and overall lowest grade. Fielder was the only cultivar which would have been downgraded in all environments, except at Swift Current in 1991 and 1994. The other CWSWS cultivar, AC Reed, tested in 1994 only, had similar black point incidence as Fielder at Swift Current but lower at Outlook (data not presented). Of the two white-seeded common wheats, Genesis always had lower or equal levels of black point than Fielder. Of all the wheat cultivars tested, the CWRS Katepwa consistently had low black point incidence, even under high disease pressure in 1992. Katepwa and the CPS cultivars Biggar, Genesis, and AC Taber were the only ones that would not have been downgraded beyond No. 2 in any of the environments (Table 3). The grade tolerance levels for black point in the CPS class are higher than in the other quality classes.

Single degree of freedom contrasts showed that there were no significant differences $(P>0.05)$ in levels of black point between durum and common wheat in five of the environments (Table 4). The durum wheat had higher black point levels $(P<$ 0.01) than the common wheat cultivars in
1992 at both locations and in 1994 at Outlook. There would have been more downgrading of the durum than of the common wheat cultivars in 1992 (Table 3). The two 1992 environments had higher overall black point levels at both locations in 1992 than in the rest, which could be attributed to above-average precipitation during seed development and delayed ripening.

We conclude that there were individual varietal differences in black point levels within each of the species, but that there were no significant differences in susceptibility to black point between the durum and common wheat cultivars in most environments. The observation that durum wheat had higher black point levels than common wheat in three of the environments suggests that durum wheat kernels could be more severely discolored than those of common wheat under certain conditions, mostly not typical of southern Saskatchewan.

\section{ACKNOWLEDGMENTS}

We thank H. Campbell, G. Larson, and L. Thiessen for technical assistance.

\section{LITERATURE CITED}

1. Baker, R. J. 1988. Tests for crossover genotype-environmental interactions. Can. J. Plant
Sci. 68:405-410.

2. Canadian Grain Commission 1994. Grain Grading Handbook for Western Canada, Canadian Grain Commission, Manitoba.

3. Conner, R. L. 1987. Influence of irrigation timing on black point incidence in soft white spring wheat. Can. J. Plant Pathol. 9:301-306.

4. Conner, R. L., and Davidson, J. G. N. 1988. Resistance in wheat to black point caused by Alternaria alternata and Cochliobolus sativus. Can. J. Plant Sci. 68:351-359.

5. Conner, R. L., and Kuzyk, A. D. 1988. Black point incidence in soft white spring wheat in southern Alberta and Saskatchewan between 1982 and 1987. Can. Plant Dis. Surv. 68:2731.

6. Fernandez, M. R., Clarke, J. M., DePauw, R. M., Irvine, R. B., and Knox, R. E. 1994. Black point and red smudge in irrigated durum wheat in southern Saskatchewan in 19901992. Can. J. Plant Pathol. 16:221-227.

7. Kilpatrick, R. A. 1968. Factors affecting black point of wheat in Texas, 1964-67. Texas Agric. Exp. Stn. Misc. Publ. 884:3-11.

8. Machacek, J. E., and Greaney, F. J. 1938. The "black point" or "kernel smudge" disease of cereals. Can. J. Res. 16:84-113.

9. Southwell, R. J., Wong, P. T. W., and Brown, J. F. 1980. Resistance of durum wheat cvs. to black point caused by Alternaria alternata. Aust. J. Agric. Res. 31:1097-1101.

10. Williams, P. M. 1997. Black point of wheat: in vitro production of symptoms, enzymes involved, and association with Alternaria alternata. Aust. J. Agric. Res. 48:13-19. 